\title{
A Temperature Index Model to Estimate Long-term Freeze-risk of Satsuma Mandarins Grown on the Northern Coast of the Gulf of Mexico
}

\author{
R.C. Ebel'1, B.L. Campbell ${ }^{2}$, M.L. Nesbitt ${ }^{3}$, W.A. Dozier ${ }^{4}$, J.K. Lindsey ${ }^{5}$, and B.S. Wilkins ${ }^{6}$ \\ Department of Horticulture, 101 Funchess Hall, Auburn University, Auburn, AL 36849
}

\begin{abstract}
AdDitional INDEX WORDs. Citrus unshiu, Poncirus trifoliata, cold hardiness, acclimation
Abstract. Estimates of long-term freeze-risk aid decisions regarding crop, cultivar, and rootstock selection, cultural management practices that promote cold hardiness, and methods of freeze protection. Citrus cold hardiness is mostly a function of air temperature, but historical weather records typically contain only daily maximum $\left(T_{\text {max }}\right)$ and minimum $\left(T_{\min }\right)$ air temperatures. A mathematical model was developed that used $T_{\max }$ and $T_{\min }$ to estimate air temperature every hour during the diurnal cycle; a cold-hardiness index $\left(\mathrm{CHI}_{500}\right)$ was calculated by summing the hours $\leq 10^{\circ} \mathrm{C}$ for the 500 $h$ before each day; and the $\mathrm{CHI}_{500}$ was regressed against critical temperatures $\left(\mathrm{T}_{\mathrm{c}}\right)$ that cause injury. $\mathrm{The}_{\mathrm{CHI}} \mathrm{CHo}$ was calculated from a weather station located within $0.1 \mathrm{~km}$ of an experimental grove and in the middle of the satsuma mandarin (Citrus unshiu Marc.) industry in southern Alabama. Calculation of $\mathbf{C H I}_{500}$ was verified by regressing a predicted $\mathrm{CHI}_{500}$ using $\mathrm{T}_{\max }$ and $\mathrm{T}_{\min }$, to a measured $\mathrm{CHI}_{500}$ calculated using air temperatures measured every hour for 4 winter seasons (1999-2003). Predicted $\mathrm{CHI}_{500}$ was linearly related to measured $\mathrm{CHI}_{500}\left(r^{2}=0.982\right)$. However, the slope was a little low such that trees with a $\mathrm{CHI}_{500}=400$, near the maximum cold-hardiness level achieved in this study, had predicted $T_{c}$ that was $0.5{ }^{\circ} \mathrm{C}$ lower than measured $T_{c}$. Predicted and measured $T_{c}$ were similar for nonhardened trees $\left(\mathrm{CHI}_{500}=0\right)$. The ability of predicted $\mathrm{T}_{\mathrm{c}}$ to estimate freeze injury was determined in 18 winter seasons where freeze injury was recorded. During injurious freeze events, predicted $T_{c}$ was higher than $T_{\min }$ except for a freeze on 8 Mar. 1996. In some freezes where the difference in $T_{c}$ and $T_{\min }$ was $<0.5^{\circ} \mathrm{C}$ there were no visible injury symptoms. Injury by the freeze on 8 Mar. 1996 was due, in part, to abnormally rapid deacclimation because of defoliation by an earlier freeze on 4-6 Feb. the same year. A freeze rating scale was developed that related the difference in $T_{c}$ and $T_{\min }$ to the extent of injury. Severe freezes were characterized by tree death $\left(\mathrm{T}_{c}-\mathrm{T}_{\min }>3.0^{\circ} \mathrm{C}\right)$, moderate freezes by foliage kill and some stem dieback $\left(1.0{ }^{\circ} \mathrm{C} \leq \mathrm{T}_{\mathrm{c}}-\mathrm{T}_{\min } \leq 3.0^{\circ} \mathrm{C}\right)$, and slight freezes by slight to no visible leaf injury $\left(\mathrm{T}_{\mathrm{c}}-\mathrm{T}_{\min }<1.0^{\circ} \mathrm{C}\right)$. The model was applied to $T_{\max }$ and $T_{\min }$ recorded daily from 1948 through 2004 to estimate long-term freeze-risk for economically damaging freezes (severe and moderate freeze ratings). Economically damaging freezes occurred 1 out of 4 years in the 56-year study, although 8 of the 14 freeze years occurred in two clusters, the first 5 years in the 1960s and 1980s. Potential modification of freeze-risk using within-tree microsprinkler irrigation and more cold-hardy cultivars was discussed.
\end{abstract}

Satsuma mandarins on trifoliate orange [Poncirus trifoliata (L.) Raf.] rootstock are one of the most cold hardy of the commercial citrus crops (Yelenosky, 1985). Because of their superior cold hardiness and excellent fruit quality due to the climate in this region (Ebel et al., 2004a), an industry developed on the northern coast of the Gulf of Mexico in the early 1900s that expanded to 7500 ha by 1923 (Winberg, 1948). A series of freezes and especially the last freeze in 1940 devastated the industry and later freezes discouraged its revival (Winberg, 1948). At that time, the only means of protecting trees were by banking soil around the trunk, growing trees under longeaf pine trees (Pinus palustris Mill.), and the use of smudge pots. Banking soil allowed trunks to survive, which negated the need to replant, but did not protect the majority of the canopy so that several years were required for production to fully recover. Pine trees and smudge pots offered protection from radiational freezes, but provided little protection

Received for publication 6 Dec. 2004. Accepted 4 Dec. 2004. This project was funded in part by USDA Special Research Grants OEP \#2001-03124 and OEP \#2002-06162 and the Alabama Agricultural Experiment Station. The authors would like to thank the Alabama Weather Information Service (AWIS) for providing climate data.

${ }^{1}$ Associate Professor. Corresponding author. E-mail: rcebel@acesag.auburn. edu

${ }^{2}$ Agricultural Program Assistant II.

${ }^{3}$ Agricultural Program Associate I.

${ }^{4}$ Professor

${ }^{5}$ Graduate Research Assistant.

${ }^{6}$ Field Research Associate IV. from advective freezes, which are the more severe freezes that occur in this region (Attaway, 1997).

Technological advancements that can mitigate freeze-risk have evoked strong interest in reviving the satsuma mandarin industry in this region. New methods of directly protecting trees substantially reduce freeze injury. Microsprinkler irrigation inside the canopy can protect scaffold limbs thus shortening the time it takes to get back into full production after severe freezes that kill whole, unprotected trees (Bourgeois and Adams, 1987; Bourgeois et al., 1990; Nesbitt et al., 2000). Plastic high tunnel houses can provide substantial freeze protection, but their expense deters widespread commercial use. More cold-tolerant cultivars and rootstocks may also reduce risk of freeze loss. Selections of satsuma mandarins were made in China based on survival from a $-12{ }^{\circ} \mathrm{C}$ freeze (H. Huang, personal communication), and there is some preliminary evidence that they may be more cold hardy than current commercial cultivars (R.C. Ebel, unpublished data; Zhang et al., 2002). Genetic manipulation may also provide means of enhancing cold hardiness (Iba, 2002; Wisniewski et al., 2003), although much research still needs to be conducted before genetically modified crops can be developed that reduce freeze-risk.

Estimating freeze-risk and its modification by various freeze protection measures would benefit development of the satsuma mandarin industry on the northern coast of the Gulf of Mexico. Mathematical models that predict subfreezing temperatures that cause injury have been developed for several crops (Andrews et al., 1987; Fuchigami and Nee, 1987; Gay and Eagles, 1991; 
Kobayashi et al., 1983), but not for subtropical crops such as citrus. Air temperatures preceding a freeze are the most important climate factor affecting the level of citrus cold hardiness (Yelenosky et al., 1984; Yelenosky, 1991a, 1985, 1996). The objective of this study was to use air temperature records from a site in the satsuma mandarin growing region on the northern coast of the Gulf of Mexico to generate a model that predicts freeze injury. The model was verified by recorded injurious freeze events of a satsuma mandarin grove for 18 winter seasons. Long-term risk was determined using recorded maximum and minimum air temperature since 1948. Mitigation of freeze-risk by microsprinkler irrigation and superior cold-hardy cultivars is discussed.

\section{Materials and Methods}

Theoretical DeVelopment OF THE MODEL. The mathematical model that predicts temperatures that cause injury to satsuma mandarins based on maximum $\left(\mathrm{T}_{\max }\right)$ and minimum $\left(\mathrm{T}_{\min }\right)$ air temperature was developed in four steps.

First, fractional daylength was calculated using the approach of France and Thornley (1984). The calculations required latitude at the site where weather records were recorded. We used a zenith angle of $90.83^{\circ}$, which occurs when the top of the sun's disc just touches the horizon for a sea level observer. Variables calculated included year angle, which is the period of 1 year that corresponds to $360^{\circ}$; solar declination, which is the line joining the sun and earth at the equatorial plane, and is $\pm 23.45^{\circ}$ at the summer and fall solstices, respectively; and solar hour angle, which is the difference between the actual time of day and the time of apparent noon. These series of calculations allowed calculation of daylength, which is the fraction of the 24-h day where the top of the sun's disc was above the horizon. This approach to determining daylength was shown to be accurate to within $0.002 \mathrm{~d}$, and can be used for any location where latitude is known.

The second step in development of the model was to estimate hourly temperatures from daily $\mathrm{T}_{\max }$ and $\mathrm{T}_{\min }$, which are the only records available before modern electronic, automated data collection equipment allowed storage of hourly temperature values and other climate variables. On days unperturbed by weather fronts, $\mathrm{T}_{\text {min }}$ occurs immediately before dawn and $\mathrm{T}_{\max }$ occurs $4 \mathrm{~h}$ before sunset. To facilitate development of equations, the 24-h period from sunrise to sunrise the next day was used. Estimates of hourly air temperatures were according to the approach of Cesaraccio et al. (2001) where hourly temperatures were determined using three equations:

For $\mathrm{h}_{\mathrm{sr}}<\mathrm{h} \leq \mathrm{h}_{\max }: \quad \mathrm{T}_{\mathrm{h}}=\mathrm{T}_{\mathrm{sr}}+\left(\mathrm{T}_{\max }-\mathrm{T}_{\mathrm{sr}}\right) \sin \left[\left(\mathrm{h}-\mathrm{h}_{\mathrm{sr}}\right) /\left(\mathrm{h}_{\max }-\mathrm{h}_{\min }\right)(\pi / 2)\right]$ Eq. $1 \mathrm{a}$

For $\mathrm{h}_{\max }<\mathrm{h}<\mathrm{h}_{\mathrm{ss}}: \quad \mathrm{T}_{\mathrm{h}}=\mathrm{T}_{\mathrm{ss}}+\left(\mathrm{T}_{\max }-\mathrm{T}_{\mathrm{ss}}\right) \sin \left[(\pi / 2)+\left(\left(\mathrm{h}-\mathrm{h}_{\max }\right) / 4\right)(\pi / 2)\right]$ Eq. $1 b$

For $\mathrm{h}_{\mathrm{ss}}<\mathrm{h} \leq \mathrm{h}_{24}: \quad \mathrm{T}_{\mathrm{h}}=\mathrm{T}_{\mathrm{ss}}+\left[\left(\mathrm{T}_{24}-\mathrm{T}_{\mathrm{ss}}\right) /\left(\mathrm{h}_{24}-\mathrm{h}_{\mathrm{ss}}\right)^{-1 / 2}\right]\left(\mathrm{h}-\mathrm{h}_{\mathrm{ss}}\right)^{1 / 2} \quad$ Eq. 1c

Hour $(h)$ variables were defined at sunrise $\left(h_{\text {sr }}\right)$, the hour $T_{\max }$ occurred $\left(\mathrm{h}_{\max }\right)$, sunset $\left(\mathrm{h}_{\mathrm{ss}}\right)$, and sunrise the next morning $\left(\mathrm{h}_{24}\right)$. Air temperature (T) used the same subscript variables as used for hour. The temperature at sunset $\left(\mathrm{T}_{\mathrm{ss}}\right)$ was approximated using $\mathrm{T}_{\mathrm{ss}}=$ $\mathrm{T}_{\max }-\mathrm{C}\left(\mathrm{T}_{\max }-\mathrm{T}_{24}\right)$, where $\mathrm{C}$ was a constant empirically derived by Cesaraccio et al. (2001) by comparing best fit models to data sets with known hourly temperature values and was set at 0.39 .

The third step in development of the model was to calculate a cold-hardiness index (CHI). Cold acclimation is a function of many environmental and biotic factors, however, air temperatures preceding a freeze have the largest impact on citrus (Yelenosky et al., 1984; Yelenosky, 1978a, 1985, 1991a, 1996; Young, 1961). Citrus trees acclimate to subfreezing temperatures when air temperature is $\leq 10{ }^{\circ} \mathrm{C}$ (Yelenosky, 1991a). Although the ideal relationship between air temperature and acclimation or deacclimation rate is likely a curve, there is insufficient data for accurate development of a regression that would describe that relationship. Each hour $\leq 10^{\circ} \mathrm{C}$ was assigned a value of one and each hour $>10^{\circ} \mathrm{C}$ was assigned a value of zero. Yelenosky (1991a; Yelenosky et al., 1984) concluded that $500 \mathrm{~h}(\approx 3$ weeks) of air temperatures $\leq 10{ }^{\circ} \mathrm{C}$ were required for citrus to acquire maximum cold hardiness. Total cold-hardiness level before the start of each day was calculated using:

$$
\mathrm{CHI}_{500}=\sum_{\mathrm{h}=1}^{500} \mathrm{CHI}_{\mathrm{h}} \quad \text { Eq. } 2
$$

where $\mathrm{CHI}_{h}$ was the cold-hardiness index value (0 or 1 ) for each hour, and $\mathrm{CHI}_{500}$ was the sum of cold-hardiness index values for the $500 \mathrm{~h}$ before the start of each day.

The fourth step in development of the model was to regress depth of acclimation to temperatures that cause injury. Citrus tree organs vary in cold tolerance, with leaves more sensitive to subfreezing temperatures than stems and trunks (Nesbitt et al., 2002; Yelenosky 1985). Leaves are important for current season's production and therefore consistent cropping (Ebel et al., 2000), so their hardiness was used to estimate the upper limit of injury. The upper limit of the model should correspond to injury that typically occurs for nonhardened leaves, which occurs at higher temperatures than cold-hardened leaves (Nesbitt et al., 2002). Injury occurs within $30 \mathrm{~min}$ after ice begins to form, which is about $-4{ }^{\circ} \mathrm{C}$ for nonhardened satsuma mandarin leaves (Ebel et al., 2004b). In both cold-hardened and nonhardened citrus trees, one or a few sites promote crystallization of water, and additional water crystallizes to the ice creating an ice/water front that spreads throughout the entire canopy at rates up to $60 \mathrm{~cm} \cdot \mathrm{min}^{-1}$ (Yelenosky, 1991b). Because the entire canopy freezes rapidly and ice begins to form around $-4^{\circ} \mathrm{C}$, this temperature was used as the upper limit of the model. The lower limit of the model would correspond to killing temperatures of stems of fully cold-hardened trees, which was shown to be about $-10^{\circ} \mathrm{C}$ (Nesbitt et al., 2002). This lowest theoretical limit of stem hardiness was used as the lower limit of the model and corresponded to the full $500 \mathrm{~h}$ below $10^{\circ} \mathrm{C}$. Using $-4.0^{\circ} \mathrm{C}$ where $\mathrm{CHI}_{500}=0$, and $-10^{\circ} \mathrm{C}$ where $\mathrm{CHI}_{500}=500$, a linear regression was derived to predict the critical temperature $\left(\mathrm{T}_{\mathrm{c}}\right)$ at which injury would occur:

$$
\mathrm{T}_{\mathrm{c}}=\left(\mathrm{CHI}_{500} \times-0.012{ }^{\circ} \mathrm{C}\right)-4.0^{\circ} \mathrm{C}
$$

where $\mathrm{CHI}_{500}$ is unitless.

Model VERIFICATION. The model was verified in four steps. First, hourly air temperature data was collected from a weather station at the Gulf Coast Research and Extension Center at Fairhope (lat. $30^{\circ} 31^{\prime} 22^{\prime \prime} \mathrm{N}$, long. $87^{\circ} 54^{\prime} 12^{\prime \prime} \mathrm{W}$ ) from 1 Sept. 1990 to 31 Mar. 2004. The weather station was located within $0.1 \mathrm{~km}$ from a satsuma mandarin grove that had been at this site throughout the temperature collection period and from which injury symptoms were recorded. The model was applied to daily $\mathrm{T}_{\max }$ and $\mathrm{T}_{\min }$ for the 1999-2000 through 2002-03 winter seasons to determine predicted hourly values. Hourly predicted values were compared 
to values measured and stored every hour, and the overall means graphically presented. The measured hourly values were also regressed against predicted hourly values with the coefficient of determination, slope and y-intercept used to determine goodness of fit. Second, the predicted $\mathrm{CHI}_{500}$ was regressed against the measured $\mathrm{CHI}_{500}$ with goodness of fit determined by the regression coefficient, slope and y-intercept. Third, since the slope of the regression of predicted and measured $\mathrm{CHI}_{500}$ was not at the ideal 1:1 relationship ( slope $=1$ ), the difference in measured and predicted $\mathrm{T}_{\mathrm{c}}$ were regressed against measured $\mathrm{CHI}_{500}$ to determine how much error in $\mathrm{T}_{\mathrm{c}}$ was introduced. Fourth, predicted $\mathrm{T}_{\mathrm{c}}$ was compared to $\mathrm{T}_{\min }$ and the injury that was recorded for 18 winter seasons for the nearby satsuma mandarin grove. All regressions were determined using the regression procedure of SAS (SAS Institute, 1985).

The satsuma mandarin grove from which injury symptoms were recorded was planted in Mar. 1990 at the Alabama Agricultural Experiment Station Gulf Coast Research and Extension Center in Fairhope. The test site was $1.6 \mathrm{~km}$ east of Mobile Bay. The grove was planted with satsuma mandarin on trifoliate orange rootstock at a $4.6 \times 7.6 \mathrm{~m}$ spacing. This cultivar and rootstock is the most commonly used in the commercial industry. Orchard management practices were according to commercial practices.

ESTIMATES OF LONG-TERM FREEZE-RISK. Based on the results for the 18 winter seasons where injury symptoms were recorded, a freeze severity rating scale was developed based on the difference between $\mathrm{T}_{\mathrm{c}}$ and $\mathrm{T}_{\min }$ and the extent of the injury. The mathematical model was applied to $\mathrm{T}_{\max }$ and $\mathrm{T}_{\text {min }}$ data with temperatures recorded daily at $1.5 \mathrm{~m}$ height using mercury thermometers in a standard temperature shelter from 1948 through 1994, and thermocouples from 1995 through 2004 . Freeze severity was determined daily for 1 Oct. through 31 Mar.

\section{Results and Discussion}

Model DEVELOPMENT, ACCURACY, AND VERIFICATION. When the model was first applied to temperature data for the 1999-2000 through the 2003-04 winter seasons, it was clear that the model under predicted $\mathrm{T}_{\mathrm{sr}}$ by $2{ }^{\circ} \mathrm{C}$ and over predicted $\mathrm{T}_{\max }$ by $0.5^{\circ} \mathrm{C}$. The cause of the variation is unclear; however, it was somewhat consistent with that reported by Cesaraccio et al. (2001) where predicted and measured air temperature varied by as much as $2^{\circ} \mathrm{C}$. To get the best fit between predicted and measured air temperature, we added $2.0^{\circ} \mathrm{C}$ to every $\mathrm{T}_{\mathrm{sr}}$ and $\mathrm{T}_{24}$, and subtracted $0.5^{\circ} \mathrm{C}$ from every $\mathrm{T}_{\max }$ before applying the model. This adjustment is small compared to the full range of temperatures in this study (-14.9 to $35.0^{\circ} \mathrm{C}$ ). The adjusted values resulted in a very close fit of the predicted to measured air temperatures (Fig. 1). The predicted diurnal curve closely approximated the measured diurnal curve (Fig. 1A). When predicted and measured air temperatures were regressed against each other (Fig. 1B), there was a very high coefficient of determination $\left(r^{2}=0.998\right)$, the slope was 0.98 , very close to the optimal 1:1 relationship (slope $=1.00)$, and the $y$-intercept was very close to the origin (y-intercept $=0.355$ ).

Although the overall average predicted and measured values were very close as depicted in Fig. 1, there was considerable variation when viewing individual hourly values (Fig. 2). The coefficient of determination was still high $\left(r^{2}=0.867\right)$ and the slope was close to the ideal 1:1 relationship (slope $=0.927$ ). The $95 \%$ confidence interval was $\pm 5^{\circ} \mathrm{C}$, and there were many data points above the upper limit of the $95 \%$ confidence interval. The extreme temperature values were due to perturbations
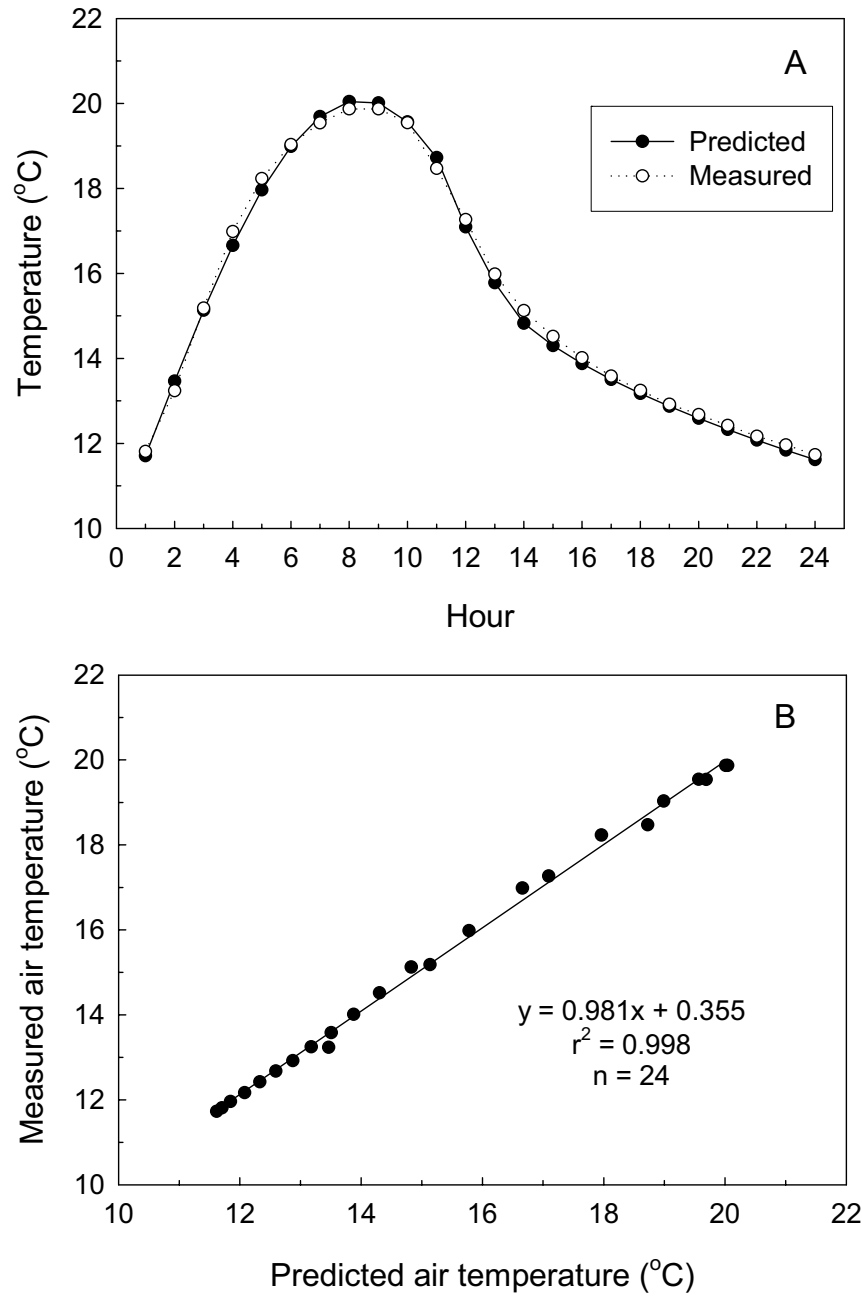

Fig. 1. Diurnal change (A) and regression analysis $(\mathbf{B})$ of air temperature predicted by the mathematical model and measured every hour by a weather station at Fairhope, Ala. Values are averaged across all days from 1 Sept. through 21 Mar. for the 1999-2000 through 2003-04 winter seasons. The first hour is sunrise.

of diurnal changes in air temperature by weather fronts. These extreme events caused deviations of the model by as much as 15 ${ }^{\circ} \mathrm{C}$ compared to measured air temperatures for some hours. The variation in this study was closer to those reported by Cesaraccio et al. (2001) for a site near the California coast that was strongly influenced by marine and continental weather, rather than sites in the inland desert regions where the variation was much lower. Because most historical temperature records do not list the time of day the maximum and minimum air temperatures occurred and cannot account for weather fronts, the variation in the model is unavoidable.

Despite the variation in hourly predicted and measured temperatures, there was a high correlation $\left(r^{2}=0.982\right)$ between the predicted and measured $\mathrm{CHI}_{500}$ (Fig. 3), indicating that the extreme variations in hourly temperature as depicted in Fig. 2 did not have a large impact on the predicted $\mathrm{CHI}_{500}$. Rather, deviations between predicted and measured air temperatures above and below the acclimation threshold of $10^{\circ} \mathrm{C}$ largely cancelled each other out. The slope was somewhat low at 0.887 indicating that the model predicted higher $\mathrm{CHI}_{500}$ compared to measured $\mathrm{CHI}_{500}$, although the $y$-intercept was very close to the origin ( $y$-intercept $=1.189$ ). The reason for the deviation in slope between the predicted and measured $\mathrm{CHI}_{500}$ is unclear. The very high number of days 


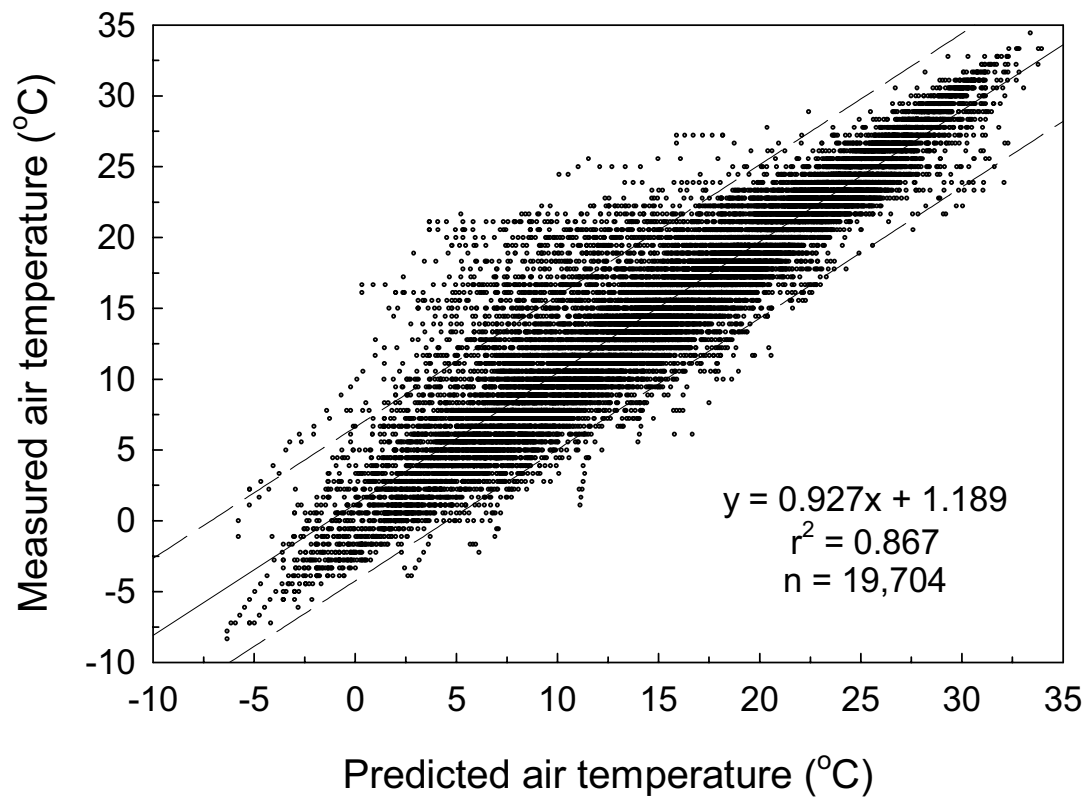

Fig. 2. Comparison of hourly predicted and measured air temperatures from 1 Sept. through 31 Mar. and for the 1999-2000 through 2003-04 winter seasons. The dashed lines indicate a 95\% confidence interval.

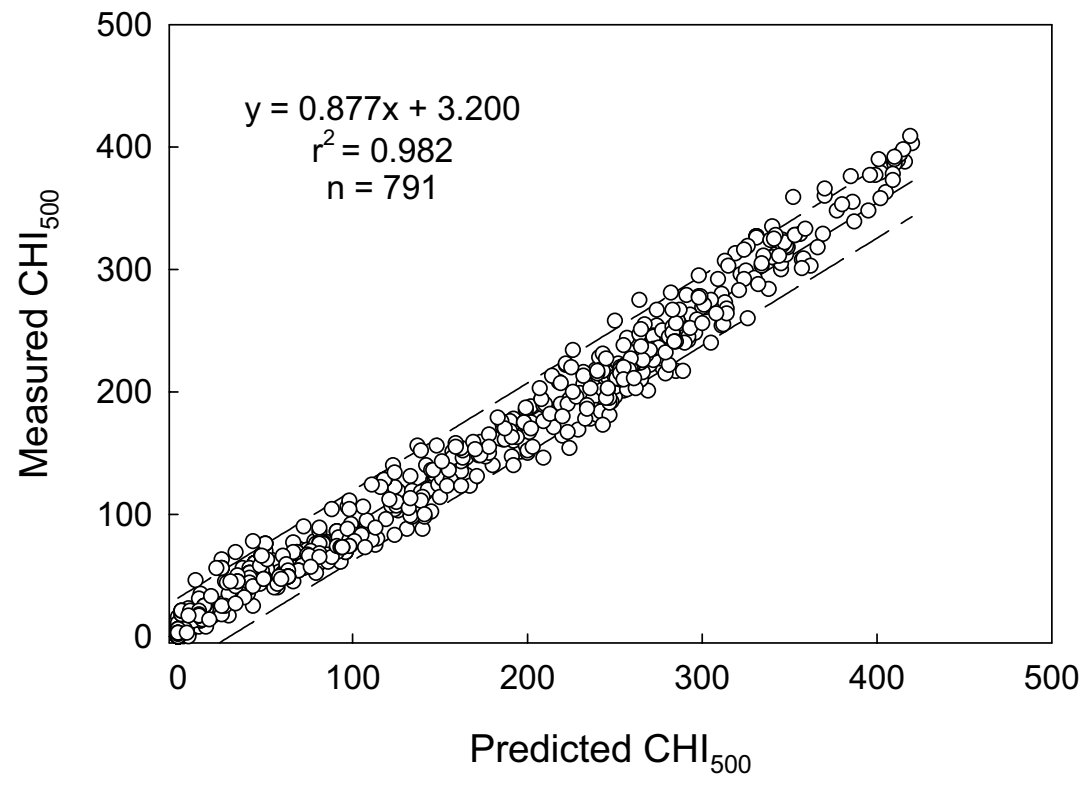

Fig. 3. Comparison of predicted and measured cold hardiness index $\left(\mathrm{CHI}_{500}\right)$ values for each day from 1 Oct. through 31 Mar. and for the 1999-2000 through 2003-04 winter seasons. $\mathrm{CHI}_{500}$ was calculated by summing the number of hours $<10^{\circ} \mathrm{C}$ for the previous $500 \mathrm{~h}$ before the start of each day (Eq. [2] in the text). The dashed lines indicate a $95 \%$ confidence interval.

where $\mathrm{CHI}_{500}$ was at or near zero confined the lower end of the regression to the origin $(y$-intercept $=3.200)$. Thus, the low slope caused increasing variation with higher $\mathrm{CHI}_{500}$ values. At $\mathrm{CHI}_{500}$ of 400, which was near the maximum $\mathrm{CHI}_{500}$ found in this study, the difference in predicted and measured $\mathrm{CHI}_{500}$ was $\approx 50$ units, which caused predicted $\mathrm{T}_{\mathrm{c}}$ to be $0.5{ }^{\circ} \mathrm{C}$ lower than measured $\mathrm{T}_{\mathrm{c}}$ (Fig. 4). The $95 \%$ confidence interval was $\pm 0.4{ }^{\circ} \mathrm{C}$ and maximum deviation of predicted and measured critical temperatures was about $\pm 0.85^{\circ} \mathrm{C}$. These deviations are reasonable considering that the full range of $\mathrm{T}_{\mathrm{c}}$ was from -4.0 to $-10.0{ }^{\circ} \mathrm{C}$.

The final verification of the model was to compare predicted $\mathrm{T}_{\mathrm{c}}$ to actual recorded minimum temperatures during freeze events and compare the differences to observed injury. The injury records from the Gulf Coast Research and Extension Center in Fairhope from 1989 through 2004, plus the known killing freezes of the 1961-62, 1983-84, and 1984-85 winter seasons represents 18 winter seasons to validate the model. The freezes of the 1961-62, 1983-84, 1984-85, and 1989-90 winter seasons killed whole trees (Table 1). The minimum air temperatures dipped below the $-10.0^{\circ} \mathrm{C}$ critical minimum temperature for trees at maximum cold hardiness. After the devastating freeze of the 1989-90 winter season, the model predicted five freezes. The freeze of 4-6 Feb. during the 1995-96 winter season was characterized by night temperatures dipping below $\mathrm{T}_{\mathrm{c}}$ for a few short hours each night, and the difference between $\mathrm{T}_{\mathrm{c}}$ and the minimum air temperature reached a maximum of $2.8^{\circ} \mathrm{C}$. This freeze caused complete leaf kill and some shoot dieback but no other injury. The freeze during the 1996-97 winter season caused slight leaf injury and the difference between $T_{c}$ and the minimum air temperature was only $0.6^{\circ} \mathrm{C}$. The freezes of $1990-91$ and 2000-01 caused no visible injury and had differences in $\mathrm{T}_{c}$ and minimum air temperatures of 0.3 and $0.4{ }^{\circ} \mathrm{C}$, respectively. These freezes were of sufficiently short duration and temperatures mild enough, compared to $\mathrm{T}_{\mathrm{c}}$, that the injury was not lethal (Ebel et al., 2004b).

The freeze of 8-9 Mar. during the 1995-96 winter season was unusual in that it was the only freeze where $\mathrm{T}_{\mathrm{c}}\left(-5.7{ }^{\circ} \mathrm{C}\right)$ was lower than $\mathrm{T}_{\text {min }}$ $\left(-5.6^{\circ} \mathrm{C}\right)$. The trees had started to actively grow, and there was extensive leaf kill and some stem dieback (Nesbitt et al., 2000). This freeze followed an earlier freeze on 4-6 Feb. 1996 that had defoliated the trees, which promoted growth and rapid deacclimation. Thus, the model does not work well when earlier freezes increase tree sensitivity to subsequent freezes.

The model used a simplified $\mathrm{CHI}_{500}$ whereby air temperatures were only used to accumulate cold hardiness such that deacclimation, or the active loss of cold hardiness was not incorporated in the model. For example, air temperatures above $12^{\circ} \mathrm{C}$ have been shown to promote growth (Yelenosky, 1985, 1996; Yelenosky et al., 1984), a condition that would correspond with rapid deacclimation. In calculating $\mathrm{CHI}_{500}$, we originally attempted to develop a model that included deacclimation by assigning each hour $\leq 10^{\circ} \mathrm{C}$ a value of one, each hour between 10 and $12^{\circ} \mathrm{C}$ a value of zero, and each hour $\geq 12^{\circ} \mathrm{C}$ a value of negative one. However, $\mathrm{T}_{\mathrm{c}}$ clearly over-predicted the number of freeze events that would have occurred, so we abandoned that approach. Air temperatures often rise above $12{ }^{\circ} \mathrm{C}$ during winter months in this region (Fig. 5), thus other factors must prevent deacclimation since citrus species do not enter endodormancy. Other environmental factors that have been shown to affect the level of cold hardiness include soil temperature (Bevington and Castle, 1985; Khairi and Hall, 1976; Stathakopoulous and Erickson, 1966; Wilcox et al., 1983), drought stress (Wilcox et al., 1983; Yelenosky, 1978b, 1979, 1982), and light (Niijar and Sites, 


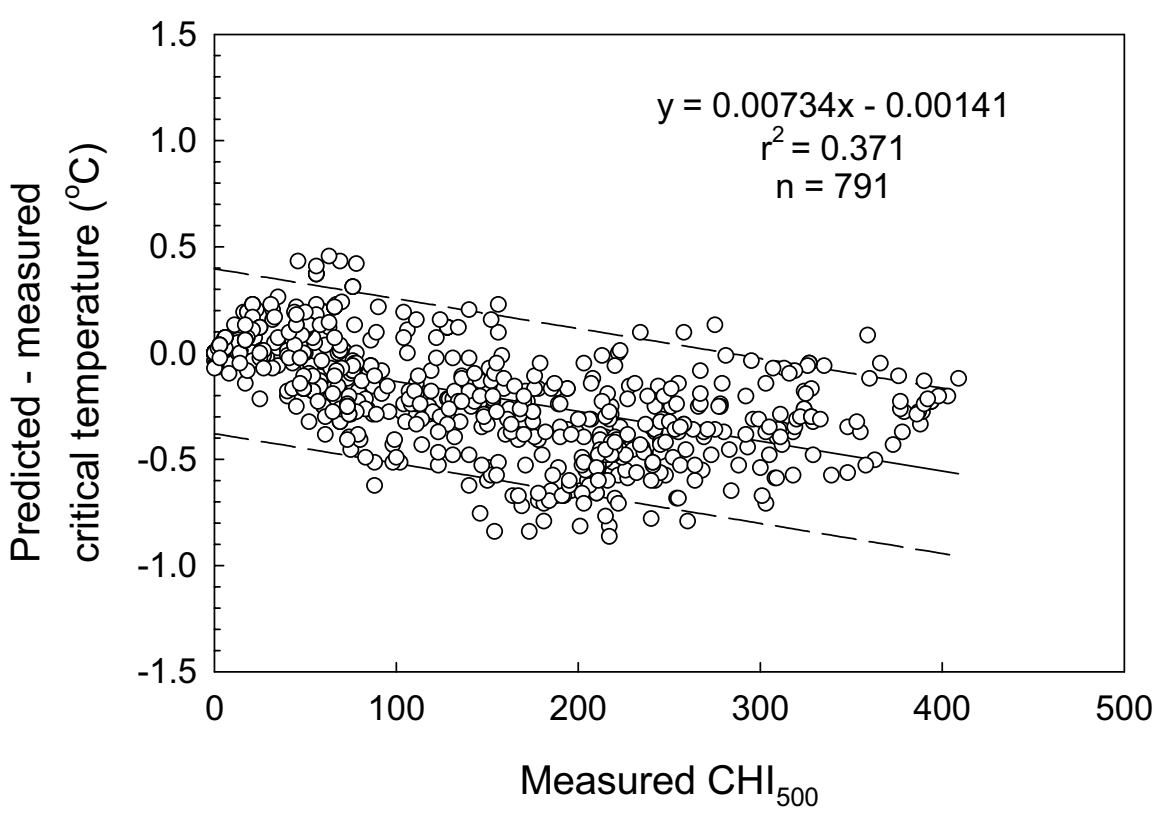

Fig. 4. Difference between predicted and measured critical temperature at which injury would occur $\left(\mathrm{T}_{\mathrm{c}}\right)$ across the range of measured cold hardiness index $\left(\mathrm{CHI}_{500}\right)$ values. Data are for each day from 1 Oct. through 31 Mar. and for the 1999-2000 through 2003-04 winter seasons. Measured CHI F00 $_{\text {was }}$ calculated by summing the number of hours $<10{ }^{\circ} \mathrm{C}$ for the previous $500 \mathrm{~h}$ before the start of each day (Eq. [2] in the text). The dashed lines indicate a $95 \%$ confidence interval.

1959; Yelenosky, 1971; Young, 1961, 1969). Drought stress in spring along the northern coast of the Gulf of Mexico is a rare occurrence, and when it does occur, it has an inhibitory effect on growth. Light tends to have a minor effect on cold hardiness, although with the growing daylength in spring it would promote growth to some extent (Niijar and Sites, 1959; Yelenosky, 1971; Young, 1961, 1969). Soil temperatures below $22^{\circ} \mathrm{C}$ (Bevington and Castle, 1985), $15^{\circ} \mathrm{C}$ (Khairi and Hall, 1976), $13{ }^{\circ} \mathrm{C}$ (Stathakopoulous and Erickson, 1966), and $10^{\circ} \mathrm{C}$ (Wilcox et al., 1983) have been shown to inhibit root growth. There were significant periods in this study when soil temperatures were below these temperatures, even in March when shoot growth normally resumes (Table 2). It is likely that soil temperatures exert a strong inhibition on deacclimation and growth during the winter months.

ESTIMATES OF LONG-TERM INJURIOUS FREEZE-RISK AND ITS MODIFICATION WITH PROTECTION MEASURES. Using freeze events where the extent of injury was recorded, we propose a freeze severity scale that includes temperature and the level of cold hardiness reached before freeze events occur. Incorporating extent of cold hardiness is critical for accurately predicting the extent of injury during a freeze (Yelenosky, 1985). For example, a freeze event where air temperature drops to $-7.0{ }^{\circ} \mathrm{C}$ would cause no injury to fully cold-hardened trees where $\mathrm{T}_{\mathrm{c}}$ is $-10{ }^{\circ} \mathrm{C}$, but would kill unhardened trees where $\mathrm{T}_{c}$ is $-4.0^{\circ} \mathrm{C}$. It is clear that the extent of damage is a function of the duration of the freeze event and the lowest temperature reached below $T_{c}$. Since air temperature typically decreases gradually to the minimum followed by a gradual increase again, the absolute minimum temperature correlates with the amount of time air temperature is below $\mathrm{T}_{\mathrm{c}}$. Thus, the difference between the minimum air temperature and $\mathrm{T}_{\mathrm{c}}$ also incorporates the duration of the freeze event, which allows comparison of the minimum air temperature and $\mathrm{T}_{\mathrm{c}}$ to develop a scale for freeze severity. We propose that severe freezes that kill whole trees occur when the minimum air temperature is more than 3.0 ${ }^{\circ} \mathrm{C}$ below $\mathrm{T}_{\mathrm{c}}$. For moderate freezes, we propose that the difference between $\mathrm{T}_{\min }$ and $\mathrm{T}_{\mathrm{c}}$ be 1.0 to $3.0^{\circ} \mathrm{C}$, which would cause extensive leaf damage and some shoot dieback. This type of freeze is economically important since leaves are important for floral and fruit retention and therefore cropping the growing season after the freeze, although the second growing season after the freeze the trees are back in full production (Ebel et al., 2000; Nesbitt et al., 2000). Slight freezes occur when minimum air temperature drops below $\mathrm{T}_{\mathrm{c}}$ by $<1.0^{\circ} \mathrm{C}$. Slight freezes would cause some leaf damage, although in some cases no injury would be visible. Some slight freezes can cause ice formation and injury as evidenced by leaf water soaking and increased electrolyte leakage, but the leaves survive after thawing and exhibit no visible injury (Ebel et al., 2004b; Young and Peynado, 1967). Slight freezes are economically unimportant since the slight leaf damage would not deter productivity, although they may enhance susceptibility to subsequent freezes (McCown, 1958; Yelenosky et al., 1984).

There were a total of 28 freeze events since 1948 that were scattered throughout the 56 years of the study (Table 1). Freeze events lasted from 1 to $5 \mathrm{~d}$ with most being 1 or 2 d. The highest $\mathrm{CHI}_{500}$ when a injurious freeze occurred was 373 units representing a $\mathrm{T}_{\mathrm{c}}$ of $-8.5^{\circ} \mathrm{C}$ and the lowest $\mathrm{CHI}_{500}$ was 97 representing a $\mathrm{T}_{\mathrm{c}}$ of $-5.2{ }^{\circ} \mathrm{C}$. The highest $\mathrm{CHI}_{500}$ that occurred in all years was 442, indicating that the trees never reached maximum cold hardiness $\left(\mathrm{CHI}_{500}=500\right)$. Maximum cold hardiness is not reached in this region because air temperatures typically increase above $10^{\circ} \mathrm{C}$ during the day throughout the winter months (Fig. 5 ). There were many days in early October and late March where $\mathrm{CHI}_{500}$ was at zero. All but one freeze occurred in December through early February, the time period characterized by highest cold hardiness. The freezes reported to have occurred from the early 1900s to 1940 also occurred during this time frame, except a killing freeze on 20 Nov. 1940 (Winberg, 1948). The 1940 freeze reached a minimum of about $-7.0^{\circ} \mathrm{C}$, however, the canopies were unhardened and completely killed.

Based on the freeze severity rating, 16\%, 11\%, and $14 \%$ of the years had slight, moderate and severe freeze, respectively, for unprotected trees (Table 3). We have preliminary evidence that satsuma mandarin selections from China may be cold hardy to $-12{ }^{\circ} \mathrm{C}$ (R.C. Ebel, unpublished data; H. Huang, personal communication; Zhang et al., 2002), so we adjusted Eq. [4] to assume that maximum cold hardiness would be $-12^{\circ} \mathrm{C}$. Applying the model then, we found that $9 \%, 11 \%$, and $11 \%$ of the years would have slight, moderate and severe injury, respectively. Genetic engineering may present an opportunity to dramatically alter maximum cold hardiness of citrus (Iba, 2002; Wisniewski et al., 2003). If satsuma mandarins were genetically modified to have maximum cold hardiness of $-15^{\circ} \mathrm{C}$, frequency of freezes would be reduced to $9 \%, 4 \%$, and $7 \%$ for slight, moderate and severe freezes, respectively. Microsprinkler irrigation has been used for freeze protection, but because of poor coverage due to high wind velocities of advective freezes, the microsprinkler heads are placed inside the canopy to protect scaffold limbs, which leaves the majority of the canopy with the fruiting wood exposed (Bourgeois and Adams, 1987; Bourgeois et al., 1990; 
Table 1. Summary of freeze events at Fairhope, Ala., from 1 Oct. 1948 through 31 Mar. 2004. Years not shown did not have freeze events injurious to satsuma mandarins as predicted by the model.

\begin{tabular}{|c|c|c|c|c|c|c|c|c|c|}
\hline \multirow[b]{2}{*}{$\begin{array}{l}\text { Winter } \\
\text { season }\end{array}$} & \multirow{2}{*}{$\begin{array}{c}\text { Date(s) of } \\
\text { freeze } \\
\text { event }\end{array}$} & \multirow[b]{2}{*}{$\mathrm{CHI}_{500}{ }^{\mathrm{z}}$} & \multirow[b]{2}{*}{$\begin{array}{l}\mathrm{T}_{\mathrm{c}}^{\mathrm{y}} \\
\left({ }^{\circ} \mathrm{C}\right)\end{array}$} & \multirow[b]{2}{*}{$\begin{array}{l}T_{\min }{ }^{x} \\
\left({ }^{\circ} \mathrm{C}\right)\end{array}$} & \multirow[b]{2}{*}{$\begin{array}{c}\left(\mathrm{T}_{\mathrm{c}}-\mathrm{T}_{\min }\right) \\
\left({ }^{\mathrm{o}} \mathrm{C}\right)\end{array}$} & \multicolumn{3}{|c|}{ Type and extent of injuryw } & \multirow{2}{*}{$\begin{array}{c}\text { Freeze } \\
\text { severity } \\
\text { rating }\end{array}$} \\
\hline & & & & & & Leaves & $\begin{array}{c}\text { Stem } \\
\text { dieback }\end{array}$ & $\begin{array}{c}\text { Whole } \\
\text { tree }\end{array}$ & \\
\hline $1950-51$ & 2-3 Feb. & 177 & -6.1 & -12.1 & 6.0 & $--^{v}$ & --- & --- & Severe \\
\hline $1951-52$ & 16 Dec. & 97 & -5.2 & -5.5 & 0.3 & --- & --- & --- & Slight \\
\hline $1957-58$ & 12 Dec. & 189 & -6.3 & -7.1 & 0.8 & --- & --- & --- & Slight \\
\hline $1961-62$ & 10-13 Jan. & 289 & -7.5 & -11.0 & 3.5 & Extensive & Extensive & Extensive & Severe \\
\hline \multirow[t]{2}{*}{$1962-63$} & 12-13 Dec. & 165 & -6.0 & -13.3 & 7.3 & --- & --- & --- & Severe \\
\hline & 24-25 Jan. & 271 & -7.3 & -13.3 & 6.0 & --- & --- & --- & Severe \\
\hline $1963-64$ & 14 Jan. & 253 & -7.0 & -7.7 & 0.7 & --- & --- & --- & Slight \\
\hline $1964-65$ & 17 Jan. & 133 & -5.6 & -7.7 & 2.1 & --- & --- & --- & Moderate \\
\hline $1965-66$ & 30 Jan. & 349 & -8.2 & -12.7 & 4.5 & --- & --- & --- & Severe \\
\hline \multirow{2}{*}{$1969-70$} & 7-9 Jan. & 282 & -7.4 & -8.3 & 0.9 & --- & --- & --- & Slight \\
\hline & 4 Feb. & 238 & -6.9 & -9.4 & 2.5 & --- & --- & --- & Moderate \\
\hline \multirow[t]{2}{*}{$1970-71$} & 20 Jan. & 244 & -6.9 & -7.1 & 0.2 & --- & --- & --- & Slight \\
\hline & $10 \mathrm{Feb}$. & 183 & -6.2 & -7.1 & 0.9 & --- & --- & --- & Slight \\
\hline $1971-72$ & 16 Jan. & 126 & -5.5 & -7.1 & 1.6 & --- & --- & --- & Moderate \\
\hline $1975-76$ & 19 Dec. & 145 & -5.7 & -6.6 & 0.9 & --- & --- & --- & Slight \\
\hline $1976-77$ & 17-19 Jan. & 373 & -8.5 & -10.5 & 2.0 & --- & --- & --- & Moderate \\
\hline $1978-79$ & 3-4 Jan. & 248 & -7.0 & -7.7 & 0.7 & --- & --- & --- & Slight \\
\hline \multirow{2}{*}{$1981-82$} & 19 Dec. & 230 & -6.8 & -7.1 & 0.3 & --- & --- & --- & Slight \\
\hline & 11-12 Jan. & 161 & -5.9 & -12.7 & 6.8 & --- & --- & --- & Severe \\
\hline $1983-84$ & 25-31 Dec. & 208 & -6.5 & -12.1 & 5.6 & Extensive & Extensive & Extensive & Severe \\
\hline $1984-85$ & 21-22 Jan. & 365 & -8.4 & -14.9 & 6.5 & Extensive & Extensive & Extensive & Severe \\
\hline \multirow{2}{*}{$1985-86$} & 15 Dec. & 144 & -5.7 & -6.0 & 0.3 & --- & --- & --- & Slight \\
\hline & 26-27 Dec. & 293 & -7.5 & -8.8 & 1.3 & --- & --- & --- & Moderate \\
\hline 1989-90 & 23-25 Dec. & 373 & -8.5 & -12.7 & 4.2 & Extensive & Extensive & Extensive & Severe \\
\hline $1990-91$ & 16-17 Feb. & 160 & -5.9 & -6.0 & 0.1 & None & None & None & Slight \\
\hline \multirow{2}{*}{$1995-96$} & 4-6 Feb. & 260 & -7.1 & -9.9 & 2.8 & Extensive & Slight & None & Moderate \\
\hline & 8-9 Mar. & 144 & -5.7 & -5.6 & -0.1 & Extensive & Slight & None & Moderate \\
\hline 1996-97 & 20-21 Dec. & 163 & -6.0 & -6.6 & 0.6 & Slight & None & None & Slight \\
\hline $2000-01$ & 20 Dec. & 250 & -7.0 & -7.1 & 0.1 & None & None & None & Slight \\
\hline
\end{tabular}

${ }^{2}$ The cold hardiness index was based on total hours $\leq 10{ }^{\circ} \mathrm{C}$ within the $500 \mathrm{~h}$ previous to the freeze.

y Critical air temperature $\left(\mathrm{T}_{c}\right)$ that would cause injury was based on $\mathrm{CHI}_{500}$ and calculated from $\mathrm{T}_{\mathrm{c}}=\left(\mathrm{CHI}_{500} \times-0.012{ }^{\circ} \mathrm{C}\right)-4.0{ }^{\circ} \mathrm{C}$.

xMinimum air temperature $\left(\mathrm{T}_{\min }\right)$ that occurred during the freeze event.

wBased on visual observations of a satsuma mandarin grove at the Gulf Coast Research and Extension Center in Fairhope, Ala.

vNot available.

uThe overall freeze severity rating scale was as followed: slight $=$ some injury to leaves, moderate $=$ extensive leaf damage and some stem dieback, and severe $=$ widespread tree death. The slight, moderate, and severe freeze ratings corresponded to $\mathrm{T}_{\mathrm{c}}-\mathrm{T}_{\min }$ of $<1.0{ }^{\circ} \mathrm{C}, 1.0{ }^{\circ} \mathrm{C}$ to $3.0{ }^{\circ} \mathrm{C}$ and $>3.0^{\circ} \mathrm{C}$, respectively.

Nesbitt et al., 2000). Severe freezes would kill the leaves and cause dieback of the fruiting wood thus eliminating productivity the year of the freeze, but with the survival of the scaffold limbs the trees would produce substantially the second year after the freeze. Thus, with the use of microsprinklers, severe freezes would cause damage similar to that of moderate freezes of unprotected trees. Microsprinklers adjust the freeze-risk by adding the severe freezes to the moderate freezes (Table 3). Since microsprinklers do not add significant heat to the upper canopy, moderate freezes would not be similar to slight freezes. Even with microsprinkler irrigation, growers can expect to lose their crop 1 out of 4 years $(25 \%)$ with current commercial cultivars (cold hardy to $-10^{\circ} \mathrm{C}$ ), but the ratio improves to almost 1 out of 5 years $(22 \%)$ with the more cold-hardy selections from China (cold hardy to $-12{ }^{\circ} \mathrm{C}$ ). Genetic modification to $-15{ }^{\circ} \mathrm{C}$ would improve the freeze-risk to about one in 9 years $(11 \%)$. Because total tree kill requires several years to regain significant productivity due to replanting and low yields until the trees fill their allotted space, microsprinkler irrigation is strongly encouraged in this region to enhance economic viability of this industry. Even with this method of freeze protection, marketing strategies would have to incorporate some years with no crop.

It should be noted that the frequencies of economically damaging freezes (moderate and severe) has been given as overall averages, which does not account for clustering of major freezes. Two major clusters of freezes occurred in the first half of the 1960s and 1980s where economically damaging freezes occurred 4 out of 5 years in both periods (Fig. 6). A smaller but significant cluster occurred in 1969 and 1971. These alternate years with two moderate freezes translate into four consecutive years without a crop. The timing of freeze clusters did not relate to average winter temperatures, which were not necessarily lower or higher than other years. However, several consecutive years in the 1950s and the early 1970s were generally warmer and had the fewest number of economically damaging freezes than other periods.

With the concerns of long-term global and regional climate change impacting agriculture, there are strong efforts by climatologists to predict future weather patterns. As these models improve, they may have utility in being compared to the model in the current paper to estimate future long-term freeze-risk. 

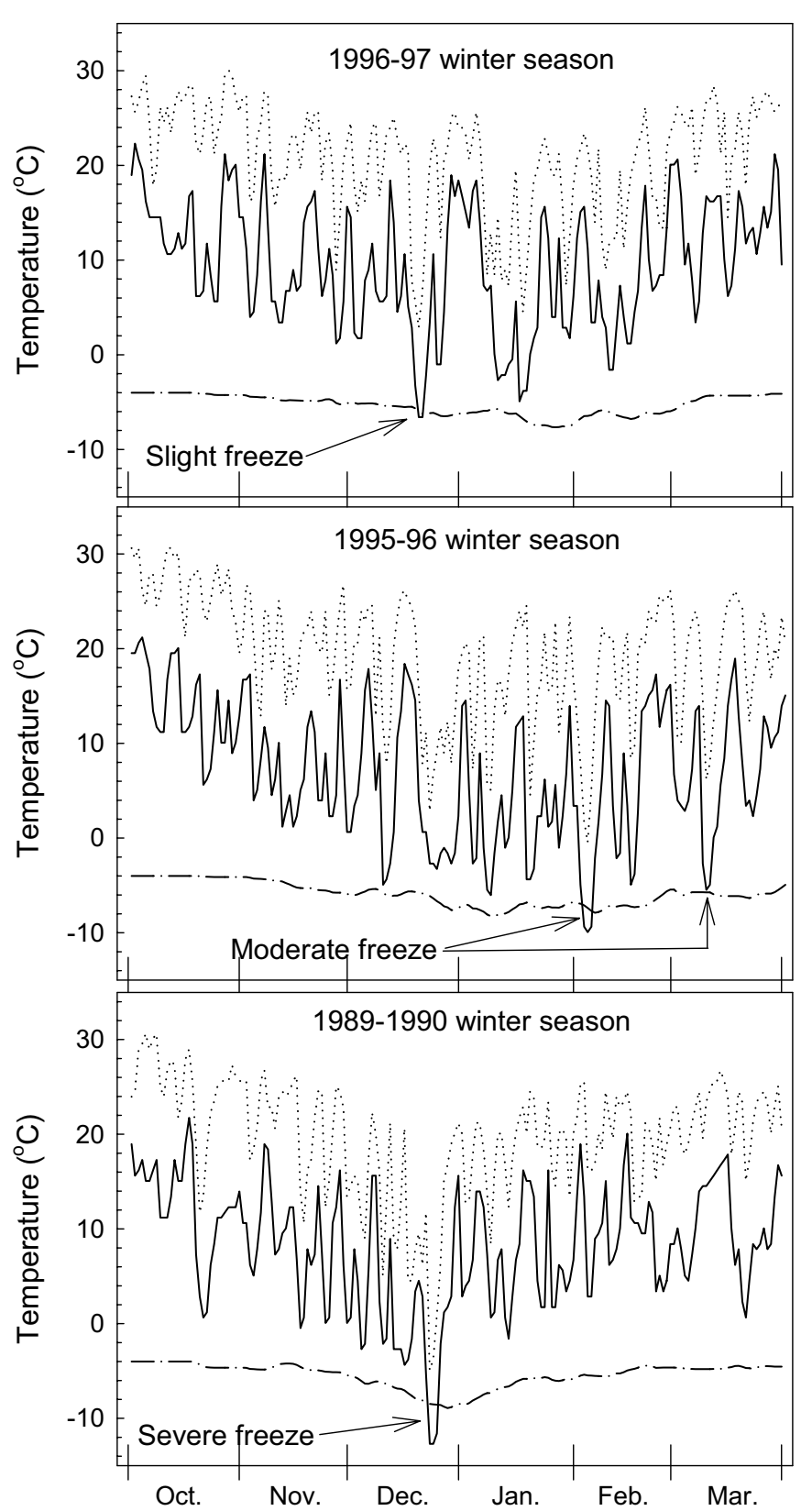

Month

Fig. 5. Examples of variation in daily maximum (dotted lines) and minimum (solid line) air temperatures, and the critical temperatures (dashed and dotted line) that would cause injury. Shown are years where freeze events caused slight (minor leaf injury), moderate (most leaves killed and some stem injury) and severe (tree kill) injury. Note that the second moderate freeze during the 1995-96 winter season did not have the minimum air temperature drop below the critical temperature that causes injury. The first freeze caused defoliation and rapid regrowth that deacclimated the trees rapidly.

Whether we are in a long-term warming trend, or in a short-term period without severe freezes such as occurred in the 1950s and 1970 s is uncertain. The model may also have utility in predicting impending freezes, however, the model may have to be modified to include other factors that affect the level of cold hardiness. Furthermore, this model was tested on one satsuma mandarin grove, other groves would have to be tested to verify the model for other situations. Current freeze forecasts begin as long as a week in advance of a cold air mass moving down from the north.
Table 2. Soil temperatures at $10.2 \mathrm{~cm}$ depth within $0.1 \mathrm{~km}$ of a satsuma mandarin grove where observations of freeze damage were measured at the Gulf Coast Research and Extension Center near Fairhope, Ala., for the years 1999 through 2004.

\begin{tabular}{lccc}
\hline & \multicolumn{3}{c}{ Soil temp $\left({ }^{\circ} \mathrm{C}\right)$} \\
\cline { 2 - 4 } Month & High & Low & Avg \\
\hline September & 31.8 & 24.6 & 28.2 \\
October & 27.8 & 20.4 & 24.1 \\
November & 22.2 & 15.3 & 18.8 \\
December & 17.2 & 10.5 & 13.9 \\
January & 15.3 & 8.4 & 11.9 \\
February & 18.6 & 11.2 & 14.9 \\
March & 22.8 & 14.8 & 18.8 \\
\hline
\end{tabular}

Table 3. Percentage of years that injurious freeze events are predicted to occur for satsuma mandarin selections at Fairhope, Ala., that vary in maximum cold hardiness $\left(-10^{\circ} \mathrm{C},-12^{\circ} \mathrm{C},-15^{\circ} \mathrm{C}\right.$ when fully coldhardened), and are either unprotected or protected by within-tree microsprinkler irrigation.

\begin{tabular}{lccccccc}
\hline & \multicolumn{4}{c}{ Maximum cold hardiness level of trees } \\
\cline { 2 - 7 } Freeze & \multicolumn{3}{c}{ Trees unprotected } & & \multicolumn{3}{c}{$\begin{array}{c}\text { Trees protected with } \\
\text { microsprinkler irrigationy }\end{array}$} \\
\cline { 2 - 4 } \cline { 5 - 7 } severity & $-10^{\circ} \mathrm{C}$ & $-12{ }^{\circ} \mathrm{C}$ & $-15^{\circ} \mathrm{C}$ & & $-10^{\circ} \mathrm{C}$ & $-12{ }^{\circ} \mathrm{C}$ & $-15^{\circ} \mathrm{C}$ \\
ratingz & $(\%)$ & $(\%)$ & $(\%)$ & & $(\%)$ & $(\%)$ & $(\%)$ \\
\hline Slight & $16^{x}$ & 9 & 9 & & 9 & 9 \\
Moderate & 11 & 11 & 4 & & 25 & 22 & 11 \\
Severe & 14 & 11 & 7 & & 0 & 0 & 0
\end{tabular}

zThe overall freeze severity rating scale were determined as slight $=$ some injury to leaves, moderate $=$ extensive leaf damage and some stem dieback, and severe $=$ widespread tree death.

yPreserves the scaffold limbs but not the outer fruiting wood during freeze events.

xIgnores the freeze 8-9 Mar. 1996.

Forecasting freezes and the injury that would occur based on the level of cold hardiness would aid freeze protection decisions by commercial growers.

\section{Literature Cited}

Andrews, P.K., E.L. Proebsting, Jr., and G.S. Lee. 1987. A conceptual model of changes in deep supercooling of dormant sweet cherry flower buds. J. Amer. Soc. Hort. Sci. 112:320-324.

Attaway, J.A. 1997. A history of Florida citrus freezes. Florida Science Source, Lake Alfred, Fla.

Bevington, K.B. and W.S. Castle. 1985. Annual root growth pattern of young citrus trees in relation to shoot growth, soil temperature, and soil water content. J. Amer. Soc. Hort. Sci. 110:840-845.

Bourgeois, W.J. and A.J. Adams. 1987. Low-volume scaffold branch irrigation for citrus freeze protection. HortScience 22:48-50.

Bourgeois, W.J., A.J. Adams, and D.R. Snipe. 1990. Effectiveness of scaffold branch irrigation for freeze protection of Louisiana citrus during 1989 freeze. Proc. Fla. State Hort. Soc. 103:62-64.

Cesaraccio, C., D. Spano, P. Duce, and R.L. Snyder. 2001. An improved model for determining degree-day values from daily temperature data. Int. J. Biometeorol. 45:161-169.

Ebel, R.C., M. Nesbitt, W.A. Dozier, B. Hockema, F.M. Woods, R. Thomas, R. McDaniel, and B.S. Wilkins. 2004a. Fruit quality of satsuma mandarin grown on the northern coast of the Gulf of Mexico. HortScience 39:979-982.

Ebel, R.C., P.A. Carter, W.A. Dozier, D.A. Findley, M.L. Nesbitt, B.R. Hockema, and J.L. Sibley. 2004b. Pattern of exotherm and electrolyte leakage measured at high frequency of satsuma mandarin exposed to subfreezing temperatures. HortScience 39:1614-1616.

Ebel, B., M. Nesbitt, D. Findley, B. Wilkins, D. Himelrick, and S. Burchett. 


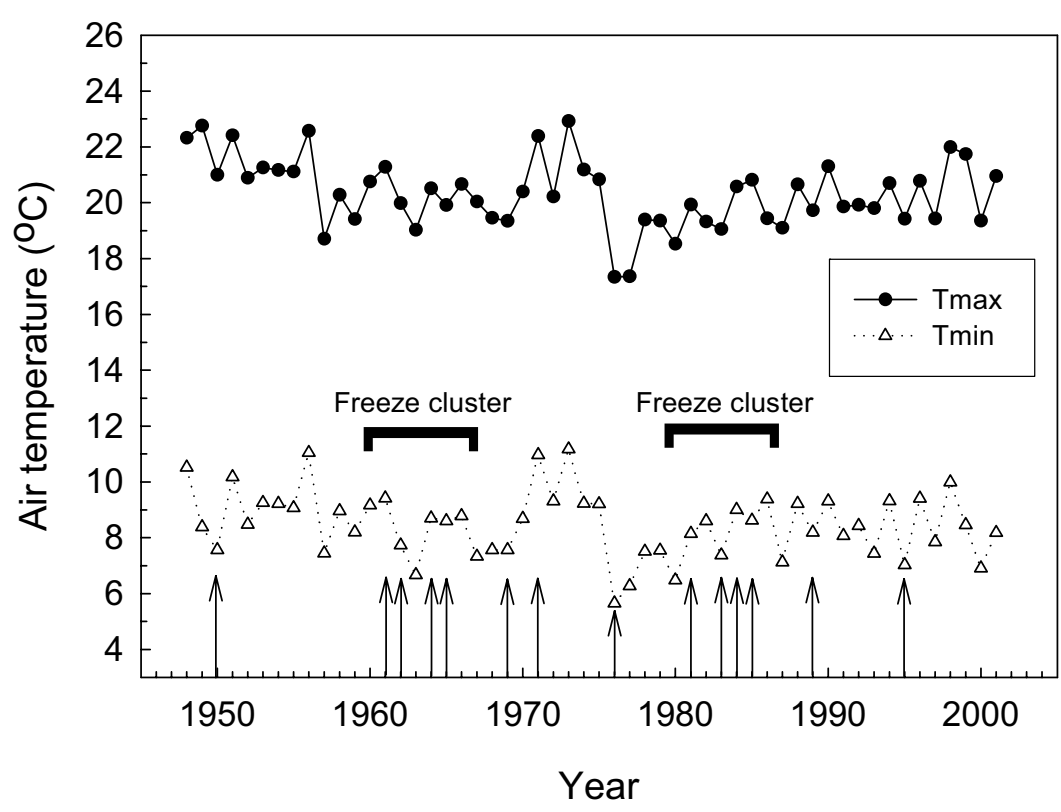

Fig. 6. Average maximum $\left(\mathrm{T}_{\max }\right)$ and minimum $\left(\mathrm{T}_{\min }\right)$ air temperatures from 1 Oct. through 31 Mar. for each year of the study. Arrows indicate economically damaging freezes (moderate and severe). Two clusters of freezes are shown.

2000. Response of satsuma mandarin to midwinter defoliation. Proc. Intl. Soc. Citricult. IX Congr., Orlando, Fla., 3-7 Dec., p. 699.

France, J. and J.H.M. Thornley. 1984. Weather, p. 95-99. In: Mathematical models in agriculture: A quantitative approach to problems in agriculture and related sciences. Butterworth, London.

Fuchigami, L.H. and C. Nee. 1987. Degree growth stage model and rest-breaking mechanisms in temperate woody perennials. HortScience 22:836-845.

Gay, A.P. and C.F. Eagles. 1991. Quantitative analysis of cold hardening and dehardening in Lolium. Ann. Bot. 67:339-345.

Iba, K. 2002. Acclimative response to temperatures stress in higher plants: Approaches of gene engineering for temperature tolerance. Annu. Rev. Plant Biol. 53:225-246.

Khairi,M.M.A. and A.E. Hall. 1976. Effects of air and soil temperatures on vegetative growth of citrus. J. Amer. Soc. Hort. Sci. 101:337-341.

Kobayashi, K.D., L.H. Fuchigami, and C.J. Weiser. 1983. Modeling cold hardiness of red-osier dogwood. J. Amer. Soc. Hort. Sci. 108:376-381.

McCown, J.T. 1958. Field observations of Florida citrus following the 1957-1958 freezes. Proc. Fla. State Hort. Soc. 71:152-157.

Nesbitt, M. L., R.C. Ebel, W.A. Dozier, N.R. McDaniel, and D. G. Himelrick. 2000. Performance of satsuma mandarin protected from freezing temperatures by microsprinkler irrigation. HortScience 35:856-859.

Nesbitt, M. L., R.C. Ebel, D. Findley, B. Wilkins, F. Woods, and D. Himelrick. 2002. Assays to assess freeze injury of satsuma mandarin. HortScience 37:871-877.
Niijar, G.S. and J.W. Sites. 1959. Some effects of day length and temperature on cold hardiness in citrus. Proc. Fla. State Hort. Soc. 72:106-109.

SAS Institute. 1985. SAS/STAT guide for personal computers, ver. 6. SAS Inst., Cary, N.C.

Stathakopoulos, W.L. and L.C. Erickson. 1966. The effect of temperature on bud break in Poncirus trifoliata. Proc. Amer. Soc. Hort. Sci. 89:222-227.

Wilcox, D.A., F.S. Davies, and D.W. Buchanan. 1983. Root temperature, water relations, and cold hardiness in two citrus rootstocks. J. Amer. Soc. Hort. Sci. 108:318-321.

Winberg, O.F.E. 1948. The satsuma, p. 1-2. In: Fairhope Courier (daily periodical), Fairhope Ala. Nov. 1948.

Wisniewski, M., C. Bassett, and L.V. Gusta. 2003. An overview of cold hardiness in woody plants: Seeing the forest through the trees. HortScience 38:952-959.

Yelenosky, G. 1971. Effect of light on cold-hardening of citrus seedlings. HortScience 6:234-235.

Yelenosky, G. 1978a. Cold hardening of 'Valencia' orange trees to tolerate $-6.7^{\circ} \mathrm{C}$ without injury. J. Amer. Soc. Hort. Sci. 103:449-452.

Yelenosky, G. 1978b. The effect of withholding water on cold hardiness of 'Valencia' orange and 'Star Ruby' grapefruit trees in controlled freezes. Proc. Fla. State Hort. Soc. 91:18-21.

Yelenosky, G. 1979. Water-stress-induced cold hardening of young citrus trees. J. Amer. Soc. Hort. Sci. 104:270-273.

Yelenosky, G. 1982. Indicators of citrus cold-hardening in the field. Proc. Fla. State Hort. Soc. 95:7-10.

Yelenosky, G. 1985. Cold hardiness in citrus. Hort. Rev. 7:201-238.

Yelenosky, G. 1991a. Minireview: Responses and adaptations of citrus trees to environmental stresses. Israel J. Bot. 40:239-250.

Yelenosky, G. 1991b. Apparent nucleation and freezing in various parts of young citrus trees during controlled freezes. HortScience 26:576-579.

Yelenosky, G. 1996. An overview of Florida citrus freeze survival. Proc. Fla. State Hort. Soc. 109:118-123.

Yelenosky, G., C.J. Hearn, and D.J. Hutchison. 1984. Nonhardening temperatures-Major factor in freeze damage to citrus trees in December 1983. Proc. Fla. State Hort. Soc. 97:33-36

Young, R.H. 1961. Influence of day length, light intensity, and temperature on growth, dormancy, and cold-hardiness of Red Blush grapefruit trees. Proc. Amer. Soc. Hort. Sci. 78:174-180.

Young, R.H. 1969. Cold hardening in citrus seedlings as related to artificial hardening conditions. J. Amer. Soc. Hort. Sci. 94:252-254.

Young, R. and A. Peynado. 1967. Freezing and water-soaking in citrus leaves. Proc. Amer. Soc. Hort. Sci. 91:157-162.

Zhang, C., M. Nesbitt, F. Dane, and B. Ebel. 2002. Cold hardiness and genetic relationships among satsuma mandarin cultivars. Amer. Soc. Hort. Sci. and the Intl. Soc. Hort. Sci. joint annual meeting, Toronto, Canada, 10-16 Aug., XXVIth Intl. Hort. Congr. \& Exhibition, p. 504-505 (Abstr.). 